DOI: $10.15290 / \mathrm{bsl} .2014 .05 .10$

\title{
Elżbieta Sidoruk
}

Uniwersytet w Białymstoku

e-mail: e.sidoruk@gazeta.pl

\section{„Jestem urodzonym wędrowcem". O miejscach autobiograficznych Sławomira Mrożka}

W Dzienniku pod datą 15 maja 1988 roku Sławomir Mrożek, zastanawiając się, dlaczego "potencjał kontemplacji” jest w nim zablokowany, a czas mija mu "na próbach unikania krajobrazu [...] i świata”, w którym żyje, zanotował:

Przez wszystkie te lata czekałem na jakieś wyjaśnienie, na coś, co koniecznie nadejdzie z zewnątrz i ujawni mi się, zmieniając moje życie i pokazując drogę. Czekanie samo się zużyło. Tymczasem uczucie podstawowego niespełnienia utrzymuje się. Innymi słowy: w wieku 58 lat nie jestem kimś, kto czuje, że osiągnął Coś, to Coś i teraz to kwestia kontynuacji, ukoronowanej ostatecznie końcowym zwieńczeniem.

Tak jak widzę resztę tego, co zostało - jestem gotów na ostatnią wspaniałą przygodę, ostatni wzlot, ostatni wyjazd, po którym spodziewam się, po którym mam nadzieję na finałowy etap długiej, ustalonej i ciągłej pracy w domu. Jeśli ta wizja się zrealizuje, będę uważał swoje życie za poprawne, swoje przeznaczenie za wypełnione.

Nigdy nie pasowałem do żadnej formy życia, która została mi przydzielona albo którą sam wybrałem. Zawsze było tak, jakby wszystko było tymczasowe, jedynie przygotowaniem do czegoś innego, po prostu stacją, ale nigdy celem podróży. [...] Zawsze było mi nieswojo, we wszystkich sytuacjach, ale akceptowałem ten dyskomfort jako przejściową i konieczną cenę procesu zbliżania się do czegoś, o czym nigdy nie wiedziałem, czym mogłoby być. Teraz najwyraźniej również nie pasuję do sytuacji. [...] Jeśli sytuacja się nie zmieni - nic się nie zmieni ${ }^{1}$.

1 S. Mrożek, Dziennik, t. 3: 1980-1989, Kraków 2013, s. 752-753. 
"Ostatnią wspaniałą przygodą", do której pisarz czuł się wówczas gotowy, miał być wyjazd do Meksyku. 30 listopada 1988 roku, podczas pobytu w Sztokholmie, Mrożek zapisał w Dzienniku: „Czas do Meksyku, ziemi mojej obiecanej. Tam usiąść naprzeciw czasu ostatniego, tam Komandor mój i tam mnie zaprasza" 2 , a w grudniu następnego roku ostatecznie opuścił Paryż, w którym mieszkał przez 23 lata, i osiedlił się na Rancho La Epifania, położonym w pobliżu meksykańskiego miasteczka Tlahuapan. Nieco wcześniej, w sierpniu 1989 roku, informując Gunara Brandella, iż wyjeżdża wraz z żoną "na dobre do Meksyku”, powody swojej decyzji tłumaczył koniecznością zmiany dotychczasowych „warunków egzystencjalnych":

Pod względem pisarstwa przeprowadzka do Meksyku oznacza przedefiniowanie moich warunków, całego wyobrażenia o tym, kim jest pisarz, co znaczy nim być, jak podchodzi on do rzeczywistości i jak ją chwyta. Dostatecznie się już naszwendałem, czas usiąść i zrelacjonować swoją historię. Jeśli mi się nie uda, zyskam przynajmniej pewność, że próbowałem.

Żeby to wszystko zrobić, muszę całkowicie zrewidować moje warunki egzystencjalne. Nowemu wizerunkowi musi towarzyszyć nowa sytuacja życiowa, w przeciwnym razie byłyby to tylko sny na jawie. Gdybym tu [w Paryżu - dop. E.S.] został, przearanżowanie nie byłoby możliwe, ani z powodów subtelniejszej natury, ani z przyczyn materialnych ${ }^{3}$.

Już w kilka miesięcy po zamieszkaniu na Rancho La Epifania pisarz czuł się w nim zadomowiony. W lipcu 1990 roku, po powrocie do Meksyku z Festiwalu Mrożka w Krakowie, tak opisywał Brandellowi miejsce, w którym zdecydował się osiedlić na stałe:

W drodze powrotnej spędziliśmy dziesięć dni w Paryżu. Ani i się podobało, ani nie podobało, byłem ponad to. To wszystko już dla mnie skończone, Paryż i moje życie w nim, Paryż reprezentuje dla mnie Europę. Do domu wróciliśmy 16 lipca, nocą, po dwudziestogodzinnej podróży. Gdy mówię „dom”, mam na myśli "dom” pod każdym względem. Oczywiście mieszkam w Meksyku, ale Meksyk jest nierozerwalnie związany z tym szczególnym zakątkiem w górach, który znalazłem i o który teraz się troszczę, dbam, który buduję i na którego rzecz pracuję jako na miejsce swojego ostatecznego przeznaczenia. Ta zmiana jest totalna: przez całe życie byłem tym, który wyjeżdża. Teraz stałem się tym, który przybywa. Nie przeprowadzę się już nigdy, bo znalazłem dom. O dziwo, ustatkowanie się, a więc to, czego nigdy nie cierpiałem, stało się źródłem głębokiej satysfakcji. Zamiast mnie dławić - jak byłoby wcześniej; tym razem nadeszła odpowiednia chwila i trafiły się odpowiednie okoliczności (łut szczęścia) - wyzwala we mnie nową energię 4 .

2 Tamże, s. 789.

3 S. Mrożek, G. Brandell, Listy 1959-1994, Kraków 2013, s. 280.

4 Tamże, s. 291. 
Jednak wbrew planom Mrożka La Epifania nie stała się miejscem jego „ostatecznego przeznaczenia". Sytuacja polityczna w Meksyku zmusiła go do opuszczenia rancza i przeprowadzki do Krakowa. O tym, że rozstanie z miejscem, które stało się dla niego domem „pod każdym względem”, nie było łatwe, dowodnie świadczy Dziennik powrotu pisany po podjęciu decyzji o powrocie do kraju. W zapiskach prowadzonych z zamiarem publikowania ich na bieżąco pisarz - jak to ujęła Małgorzata Czermińska - „nieoczekiwanie daje szereg barwnych migawek dotyczących jego meksykańskiej posiadło-

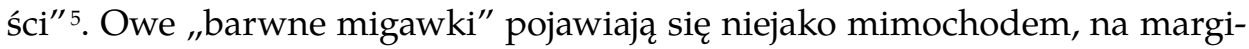
nesie refleksji towarzyszących przygotowaniom do kolejnej przeprowadzki, która miała już nie nastąpić:

A już się zanosiło na to, że nareszcie mogę sobie pozwolić na zmęczenie. Bywało, że i po kilka miesięcy nie wychodziłem za bramę, ogród jest dostatecznie duży, żebym nie czuł się więźniem. $Z$ okna, przy którym to piszę, widzę dolinę, za doliną góry, potem jeszcze góry, za którymi jest tylko Pacyfik i Chiny. Doszedłem na zachód najdalej, jak mogłem. Miałem tu zostać na zawsze i wcale mnie to nie przerażało. Tymczasem wracam do Krakowa.

No i dobrze, aby dojść najdalej, jak tylko można, to marzenie młodości i przywilej wieku dojrzałego. To mam już za sobą. Ale figurą geometryczną starości, jak się okazuje, jest koło. Idzie się, idzie i jeśli się idzie wystarczająco długo, dochodzi się do tego samego miejsca, z którego się wyszło...

No i też dobrze, jeśli takie prawo jest. Tylko to zmęczenie...

Może bym się już nie ruszył, gdybym był sam, może byłoby mi już wszystko jedno. Ale ruszę się, ruszę i zacznę wszystko od zera ${ }^{6}$.

Z założenia Dziennik powrotu miał służyć oswojeniu się z nową sytuacją, aby zaś tę funkcję spełnić, paradoksalnie musiał być pisany z myślą o czytelniku. „Te zapiski dobrze mi zrobią, ale pod warunkiem, że ktoś je przeczyta. Sam dla siebie od dawna już niczego nie zapisuję, bo to tylko nudzi i nie pomaga" [Dp, s. 8] - zanotował Mrożek na wstępie, a gdy po trzech miesiącach zaczął odczuwać znużenie ich prowadzeniem, stwierdził, że kontynuowanie dziennika mógłby usprawiedliwić jedynie w taki oto sposób: ,już nie histeryzować na swój własny temat, ale zaciekawiać czytelnika egzotycznymi opowieściami o egzotycznym kraju" [Dp, s. 51]. Istotną przeszkodą okazał się jednak fakt, że jedynym źródłem wiedzy o Meksyku było dla niego Rancho La Epifania. Opisując kraj, który znał tylko poprzez własną posiadłość, nie mógłby więc „unikać zbyt częstego powtarzania «moje»" [Dp, s. 52].

5 M. Czermińska, Miejsca autobiograficzne. Propozycja w ramach geopoetyki, „Teksty Drugie” 2011, nr 5, s. 190.

6 S. Mrożek, Dziennik powrotu, Kraków 2000, s. 18. Kolejne cytaty lokalizuję w tekście głównym, oznaczając je skrótem Dp. 
W grę nie wchodziło również opowiadanie „o ludziach, poszczególnych charakterach, żywotach, zdarzeniach", ponieważ wymagałoby zmiany gatunku literackiego i utratę sposobności, „żeby sobie czasem jęknąć, coś napisać o samym sobie" [Dp, s. 52], a to w dalszym ciągu było mu potrzebne.

Dziennik powrotu dokumentuje nie tylko niepokój powodowany stanem permanentnego zagrożenia, w jakim Mrożek i jego żona się wówczas znajdowali, ale też obawy o przyszłość miejsca, które mieli opuścić, zostawiając je pod opieką jednego z pracowników:

Mam nadzieję, że prędzej czy później Rancho się sprzeda. Mam nadzieję ze względów zrozumiałych, ale także $\mathrm{z}$ powodu następującego: wolałbym, żeby Rancho, choć dla mnie już stracone, nie zamieniło się w ruinę. Erasmo jest poczciwym chłopcem, ale takim jak wszyscy, przeciętnie nierozgarniętym, bliższym wegetacji roślinnej niż ludzkiej. Jego żona, też jak wszystkie, choć młodsza od niego, już stara - życie kobiety w Meksyku kończy się po ślubie. Zaniedbana, niechlujna, tak samo obciążona bezmyślnym fatalizmem i bezwładem jak całe życie tutaj. W tym życiu Rancho było cudem, wysepką inicjatywy, organizacji, nadziei. Nie chcę myśleć o tym, że tyle energii, woli, przedsiębiorczości i zapobiegliwości, tyle przywiązania i wreszcie miłości do tego miejsca pójdzie na marne i Rancho stanie się Atlantydą zatopioną w morzu gnijących alg. Z tym, że Rancho dla nas przeminęło, już się pogodziłem, ale żeby straszyło, gdy nas tu nie będzie, jako przydrożny pomnik rozpadu, rozkładu i klęski? Jak te krzyżyki przy Cesarskim Moście? Już bym wolał, żeby od razu zrównało się z ziemią i piękną trawą bez śladu zarosło [Dp, s. 49-50].

Być może z biegiem czasu La Epifania straciłaby swoją cudowną moc i pisarz, jako „urodzony wędrowiec", znów zacząłby odczuwać potrzebę zmiany „warunków egzystencjalnych”. Trudno jednak nie upatrywać złośliwości losu w tym, że znalazłszy w końcu, jak mniemał, miejsce "ostatecznego przeznaczenia", musiał Mrożek porzucić ranczo na zawsze z pełną świadomością faktu, iż może ono stać się przydrożnym pomnikiem „rozpadu, rozkładu i klęski".

Opisów stricte topograficznych nie ma w Dzienniku zbyt wiele. Funkcjonują one przede wszystkim jako tło przedstawianych sytuacji, a wyłaniający się z nich obraz posiadłości i okolicy jest dość szczątkowy. Jednak mimo swej migawkowości świadczy on o wyjątkowym przywiązaniu Mrożka do rancza. Zarówno z Chiavari, w którym spędził ponad 4 lata, jak i z Paryża, w którym mieszkał przez 23 lata, pisarz wyjeżdżał bez żalu, w poczuciu, że dalsze życie w tych miejscach byłoby jałowe. W grudniu 1967, tłumacząc Gunarowi Brandellowi powody, dla których postanowił przenieść się z Chiavari do Paryża, pisał:

Dłużej nie mogę tutaj trwać. To nie jest wina miejsca. Po prostu przeżyłem je do cna i nic już nie zostało. To miejsce już mnie nie karmi. Zaczyna mnie pożerać. 
Cztery i pół roku w tym małym miasteczku na wybrzeżu, z dala od wszelkiego centrum, i tak uważam, że zdałem ten sprawdzian całkiem nieźle ${ }^{7}$.

Z kolei w lutym 1989 roku, kiedy zaczęły się już krystalizować plany przeprowadzki do Meksyku, wróciwszy właśnie ze Sztokholmu zanotował w Dzienniku:

Zatrucie powietrza paryskiego, dosłownie i metafizycznie. Jesteśmy chorzy od chwili przyjazdu, prawie. Chorzy w sposób znany już, znany mi od lat.

[...]

Podczas dwóch i pół miesiąca w Sztokholmie nie zaznałem ani razu owego stanu, w jakim zawsze znajduję się, gdym w Paryżu. Ani jednej depresji. A przebyłem szpital, operację, ciężkie i burzliwe przygody w teatrze. Głos miałem dźwięczny, oko bystre, głowę mniej więcej na swoim miejscu.

Wydobycie się z Paryża nie będzie możliwe czy łatwe, jeśli nie ogłoszę stanu wyjątkowego. To musi być wojna, czyli albo on mnie, albo ja jego. Powszechna mobilizacja i środki wyjątkowe ${ }^{8}$.

Jak wynika z przywołanych powyżej wypowiedzi, Mrożek nie był bynajmniej obojętny na otaczającą go przestrzeń. W Dzienniku powrotu, obok opisów Rancho La Epifania, znajduje się fragment świadczący o tym, że związek z miejscami, w których przebywał, pisarz odczuwał nie tylko psychicznie, ale też somatycznie. Fragment ów, stanowiący relację z pierwszej po piętnastoletniej nieobecności wizyty w Polsce, a ściślej w Krakowie, jest zapisem doświadczenia przestrzeni, w której Mrożek był niegdyś zadomowiony. Doświadczenie to musiało wywrzeć na nim bardzo silne wrażenie, wspomina je już bowiem w życiorysie napisanym w 1988 roku (po angielsku) dla Gale Research (Contemporary Authors Autobiography Series) ${ }^{9}$. Co warte odnotowania, późniejsza o osiem lat wersja przedstawiona w Dzienniku powrotu jest znacznie bogatsza $\mathrm{w}$ topograficzne detale:

Przyjechałem do Krakowa wieczorem i zamieszkałem przy alei wówczas Marchlewskiego, obecnie znów Prażmowskiego, w pokoiku mojego ojca, którego akurat w Krakowie wtedy nie było, nie pamiętam już z jakich powodów. Więc przez chwilę mieszkałem sam.

Rankiem obudziło mnie dziwne uczucie, tak dziwne, że minęła chwila, zanim się zorientowałem, o co chodzi. Chodziło mianowicie o to, że na dziesiątym chyba podwórku, licząc od okna - pokoik znajdował się od strony ogródków

\footnotetext{
7 S. Mrożek, G. Brandell, Listy 1959-1994, s. 161.

8 S. Mrożek, Dziennik, t. 3: 1980-1989, s. 814-815.

9 S. Mrożek, Mój życiorys, w: tegoż, Varia, t. 1: Życie i inne okoliczności, Warszawa 2003, s. 65.
} 
i podwórek - bawiły się dzieci i ja zrozumiałem wszystko, co one mówią nawet w półśnie i nawet z tak wielkiej odległości.

[...]

Później wyszedłem na miasto. Przyjazd to był pełen emocji, nie samych przyjemnych, ale wtedy to nie $z$ winy Krakowa. Wprawdzie przyjechałem $z$ francuskim paszportem, ale to nie gwarantowało niczego.

Skręciłem z ulicy Tomasza w ulicę Jana, niegdyś Świętego Tomasza i Świętego Jana. Ulica Tomasza stała się ulicą Ludwika Solskiego, który świętym nie był. Jana nie ruszono, nie odebrano mu ulicy, choć odebrano mu Świętego. Na planie Krakowa, opublikowanym w roku 1976 przez Państwowe Przedsiębiorstwo Wydawnictw Kartograficznych w Warszawie, Jan figuruje znów jako Święty.

Skręciłem i doznałem uczucia jeszcze dziwniejszego niż o poranku. Tak dziwnego, że zawróciłem i skręciłem jeszcze raz, żeby się zorientować, o co chodzi tym razem.

Tym razem chodziło o to, że skręciło mi się z taką płynnością, z jaką skręca się koło stołu we własnym mieszkaniu. Ten narożnik (po galicyjsku „winkiel”) i moje ciało to była jedność przestrzenna, dłoń w rękawiczce i rękawiczka w dłoni. Siedliskiem mojej przygody o poranku był tylko mózg, bo tam mieści się mowa; teraz całe ciało - stopy, tułów, błędnik w uchu środkowym - brało udział w tym skręcie, jakże znajomym. Nic więc dziwnego, że tę przygodę trudniej mi było zdefiniować niż poranną. Nigdy nie mogłem w ten sposób wziąć winkla z avenue des Camps-Elysées w rue Pierre Charron, choć mieszkałem w Paryżu przez dwadzieścia dwa lata bez mała. Tu zaś winkiel przylegał do mnie, a ja do niego.

[...] Kiedyś ja tego winkla nie mogłem już znieść, i słusznie, źle by ze mną było, gdybym od niego nie odszedł daleko i na długo. Czy będzie dobrze, gdy do niego wrócę? Nie wiem, z czasem nauczyłem się nie wiedzieć [Dp, s. 28-31].

Zarówno szczegółowość opisu, jak i zastosowane w nim porównania, świadczą o tym, że Mrożek nie był pozbawiony ani wyobraźni topograficznej, ani zmysłowej wrażliwości na otaczającą go przestrzeń, co zresztą znalazło odbicie w jego twórczości literackiej, w której kategorie przestrzenne odgrywają istotną rolę ${ }^{10}$. Niemniej jednak przestrzeń przedstawiona w utworach Mrożka, mimo precyzyjnej niekiedy topografii, z zasady nie jest konkretną przestrzenią geograficzną. Jedyny bodajże wyjątek stanowi niejawnie autobiograficzne opowiadanie Moniza Clavier, którego akcja rozgrywa się w We-

10 Funkcje kategorii przestrzennych w opowiadaniach Mrożka analizuję w artykułach: Metafory przestrzenne a paraboliczność w opowiadaniach Stawomira Mrożka z tomu "Dwa listy", w: Od poetyki przestrzeni do geopoetyki, red. E. Konończuk, E. Sidoruk, Białystok 2012 oraz Być "w samym środku świata”. Metaforyka przestrzenna w "Monizie Clavier" Stawomira Mrożka, w: Geografia i metafora, red. E. Konończuk, E. Nofikow i E. Sidoruk, Białystok 2014. 
necji ${ }^{11}$. Chociaż Mrożek podróżował wiele, co teoretycznie mogłoby sprzyjać kreacji miejsc autobiograficznych, nie przejawiał skłonności do utrwalania geograficznego konkretu, który tylko w znikomym stopniu uobecnia się w Dzienniku i w korespondencji pisarza. Zapiski w Dzienniku ograniczają się najczęściej do odnotowania samego faktu wyjazdu bądź powrotu i związanego z tym stanu ducha. Na 31 stycznia 1965 Mrożek tak opisuje swój nastój przed wyjazdem do Paryża:

Nad Portofino unosi się ciemna chmura, całkiem rozmazana, cała tamta strona mglista jest, ołowiana, pełna deszczu i niepewności. O tyle symboliczne, że jutro mam zniknąć w tamtej stronie, między mną a Paryżem.

Wędrowniczek, podróżniczek, pielgrzymek, jak zawsze wyjeżdżam pełen strachu okropnego, niepewności i rozdarcia, tym bardziej, że Mara tutaj, czyli spokój, bezpieczeństwo, jasność i wiele innych spraw. [...] Tylko Paryż nie wiem, co ma znaczyć w tym wszystkim, w każdym razie czuję w tym coś patetycznego.

Dawniej Paryż oznaczałby Neapol księcia Myszkina, był nim w 1957 roku, mój pierwszy Paryż. Teraz jest to ciemna kupa wymagająca trudu selekcji, obojętny świat, neutralna straszność ${ }^{12}$.

Kolejny zapisek w Dzienniku pojawia się 1 marca 1965. Miesięczny pobyt w Paryżu zostaje przez pisarza podsumowany następująco:

Tymczasem byłem już w Paryżu, we Francji przez miesiąc, wróciłem już i siedzę przy tym samym stole, co przed miesiącem. Nie wydaje mi się jednak, żeby powtarzalność miejsc, sytuacji i przedmiotów była istotna i dała się obalić, jako powtarzalność w ogóle, przez obalenie powtarzalności miejsc, sytuacji i przedmiotów i zastąpienie ich innymi miejscami, sytuacjami i przedmiotami. Wtedy i tak miałbym uczucie powtarzalności, chociaż bardziej zakamuflowane może ${ }^{13}$.

$\mathrm{W}$ porównaniu $\mathrm{z}$ innymi zapiskami dokumentującymi powroty z podróży przywołany powyżej można uznać za obszerny. Zazwyczaj Mrożek jest znacznie bardziej lakoniczny. Niemal miesięczny pobyt w Düsseldorfie w styczniu 1966 roku skwitowany został jednym zdaniem: „Od powrotu z Niemiec nie odzyskałem stanu doczesności, żyję w stanie zawieszenia, znowu w poczekalni" ${ }^{14}$, zaś podróż do Austrii i Jugosławii w sierpniu i wrześniu tegoż roku pozostawiła w Dzienniku tylko taki ślad: „Austria, Jugosławia i z powrotem. I nic" 15 .

\footnotetext{
11 Jako utwór autobiograficzny, będący rozliczeniem Mrożka z samym sobą, interpretuję Monizę Clavier w drugim z artykułów przywołanych w przyp. 16.

12 S. Mrożek, Dziennik, t. 1: 1962-1969, Kraków 2010, s. 194.

13 Tamże, s. 195.

14 Tamże, s. 318.

15 Tamże, s. 395.
} 
Temat podróży nie pojawia się też zbyt często w listach do przyjaciół. Właściwie tylko w korespondencji ze Stanisławem Lemem Mrożek poświęca tej kwestii nieco więcej uwagi. $Z$ zasady jednak nie opisuje szczegółowo konkretnych miejsc dla nich samych, lecz traktuje opis jako pretekst do uogólniającej refleksji. Taki właśnie charakter ma wyjątkowo obszerna, bo kilkustronicowa, relacja z tygodniowej podróży po Austrii w sierpniu 1965 roku:

A właśnie byliśmy w Austrii. Tak więc, uwagę Twoją omamiwszy, niespodziewanie opisem podróży Cię chyłkiem podstąpię.

Krótko to trwało, bo kraj mały i możliwości też nieduże. W tydzień Austrię objechaliśmy, przez Villach, Wiedeń, Salzburg i Innsbruck, Brenner. Dwa tysiące sześćset kilometrów jednak. Wróciłem syty, całkiem nią znudzony, północności, galicyjskości, polskości. Bo chociaż nie duch sam oczywiście, to materia bardzo do polskości zbliżona, tyle że niby cywilizowana bardziej. Duch jest niemiecki, ale materia ta sama, którą zwłaszcza w Galicji dzieckiem byłem poczęstowany, jako tam urodzony. Chcę być dobrze zrozumiany: od Niemca jesteśmy jakże różni, ale kultura nasza materialna raczej od jego stron pochodzi, częściowo, bo z drugiej strony zmieszaliśmy ją z rosyjskością. Nie ma co się łudzić, poza pewnym specyficznym stylem warszawskim, bo zresztą każde większe miasto, a zwłaszcza każda stolica wytwarza swoją pewną odrębność, nie stworzyliśmy w materii stylu własnego, który by tylko naszym był. Nie nałożyliśmy naturze, na krajobraz naturalny, niczego, co gdzie indziej pełniej i konsekwentniej nałożono. Zresztą nawet krajobrazem niepowtarzalnie własnym nie zostaliśmy obdarzeni. I tak przez Austrię jadąc, w wielu powiatach wypisz, wymaluj albo strony Kazimierza nad Wisłą (obrzeża Dunaju w okolicy Kermu), albo wsie nasze, te zamożniejsze, albo góry podobne odnajdywałem, tyle że przeważnie większe, czystsze w rodzaju, nie tak nieśmiałe, przygaszone. Najczęściej jednak nie były to zespoły całe, ale elementy przemieszane, które wciąż do oczu wskakiwały z całości, jako nasze. Nawet okolice Mauthausen żywo przypominają okolice Oświęcimia, co nasuwa myśli, że do tych celów jakby naumyślnie wybierano okolice parszywe, nijakie, piaseczkowo bagienkowate, cherlawe, sadkowato ogródkowate, z zabudową nędznawą i nijakościowatą, dróżka jakaś, krzaczek i podwórko, bez dominanty żadnej, aby tym straszniejszy stał się kontrast między dramatycznością obozu a otoczeniem, światem zewnętrznym, a może żeby tym straszniejsza wyszła dramatyczność albo co może jeszcze straszniejsze i bardziej dramatyczne, właśnie niedramatyczność, tylko powszedniość i oczywistość obozu ${ }^{16}$.

Na zwiedzane miejsca Mrożek patrzy przez pryzmat tego, co znane, dostrzegając $\mathrm{w}$ austriackim krajobrazie przede wszystkim elementy swojskie. Fascynują go zaobserwowane podobieństwa Austrii do Polski, uwidacznia-

16 S. Lem, S. Mrożek, Listy 1956-1978, Kraków 2011, s. 449-450. 
jące się nie tylko $\mathrm{w}$ pejzażu, ale też $\mathrm{w}$ pewnych fenomenach kulturowych, które analizuje $\mathrm{w}$ ciętych, utrzymanych $\mathrm{w}$ tonie satyrycznym, komentarzach:

Kuchnia, co ważne, bo upieram się, że pokaż mi, co jesz itd., nasza, tyle że jakaś przedwojenna i jakby bardziej do oryginału zbliżona, jakbym do ojczyzny kotleta schabowego przyjechał, gulaszu i kapusty, i wędlin. [...] Cała Austria przesiąknięta jest zapachem smażeniny i kapusty, a także kirszu i cygar, na tle piwka.

Ileż podobieństwa. Nie mówię o gmachach wiedeńskich, które są oryginałami kopii krakowskich. Ale weźmy na przykład zjawisko baby. Baba zaczyna się na północ i południe od Alp i ciągnie aż do Kamczatki. W Wiedniu już możesz zobaczyć, na ulicy pustawej, jakby na Długiej, babę, co stoi przed wystawą sklepową i na stosy wypiętrzone obuwia, a na każdej parze kartka z ceną, tępo się patrzy, chustkę nawet już może mieć, tyle że jaką́s zurbanizowaną, a napis neonowy nad sklepem nowoczesny, ową specyficzną moderną, grafiką, panie święty, taką specjalną, której w innych krajach poza Niemcami i Austrią nie widziałem, a którą przejęło nasze MHD i inne skróty. W krajach łacińskich do stołu podaje ci kelner, może być nawet młody i z baczkami. Tutaj restauracje i kawiarnie to jest królestwo baby, baby tam usługują, rozliczne, mogą nawet być niestare, ale czujesz w nich babiość absolutną, baby jeszcze nie całkiem dojrzałe. [...] Baby też snują się po miastach, a ulice pustawe są i szare jakieś, do naszych zbliżone także przez to, torby niosą, nie, pani tam nie ma jako reguły, tylko jest baba, względnie jako jej forma wyemancypowana - paniusia ${ }^{17}$.

Oglądany krytycznym okiem Wiedeń, który widziany wiele lat wcześniej, wydawał się Mrożkowi na tle ówczesnego Krakowa pierwszym prawdziwym miastem, jakie w życiu zobaczył ${ }^{18}$, zostaje odczarowany. Przypomina "wielką szafę", z której wyjęto „dawną garderobę", pozostawiając na wieszakach tylko kilka sztuk:

Wszystko, co znajduje się tam w obrębie Plant, jeszcze lśni i zadaje szyku, chociaż tylko ktoś, kto po raz pierwszy wyjeżdża z Polski, daje się jeszcze nabrać na to udawanie Europy à la Paris, jak ja swego czasu. Ale cała reszta, te nieskończone szare ulice $\mathrm{z}$ czynszówkami, szczególnie wymowne $\mathrm{w}$ niedzielne popołudnie, te mnogości Alej Jerozolimskich, Krakowskiej, Długiej właśnie, do tego centrum nie przystają. W żadnym zresztą innym mieście, a jest ich tam niewiele i małe, nie czułem, że są to ludzie urodzeni z miasta i dla miasta. Wszystko to charakteryzuje się pewną powiatowością [...] ${ }^{19}$.

Tropiąc podobieństwa, Mrożek nie przeocza bynajmniej różnic. Na pierwszy rzut oka można odnieść wrażenie, że relacja z podróży po Au-

17 Tamże, s. 450-451.

18 Zob. S. Mrożek, Baltazar. Autobiografia, Warszawa 2006, s. 193.

19 S. Lem, S. Mrożek, Listy 1956-1978, s. 452. 
strii ma z założenia demistyfikatorski charakter i pisarz celowo koncentruje się na podobieństwach, a nie na tym, co niezwykłe i odrębne, by pokazać, iż nie jest już owym turystą z Polski, który dał się kiedyś nabrać na „udawanie Europy à la Paris". Mrożek dokonuje jednak korekty swoich wyobrażeń nie tylko in minus, ale także in plus. Upatrując źródła podobieństw Austrii do Polski i wschodnich stron w ogólności w swoistej chłopskości tego kraju, nie statystycznej, ale takiej, „która niewiele sobie robiąc z procesu urbanizacji jako faktu ekonomiczno-technicznego przenika do nowej formy materialnej i zwycięsko nadaje jej swojego ducha" ${ }^{20}$, właśnie ową rdzenną chłopskość, tyrolskość, uznaje za „najsilniejszą stron[ę] austriacką", dlatego, że "tylko to, co autentyczne, może być i piękne, i mocne", a taki właśnie okazał się Tyrol:

Zawsze podśmiewałem się trochę z Tyrolu, bo wydawał mi się, nie wiem dlaczego, operetkowy, tylko jodłowanie mi się z nim kojarzyło. Tymczasem na odwrót, wszystko inne, z Wiedniem razem, to coś nie tak, a Tyrol jak skała. Bardzo mnie zajął i zastanowił, a szczególnie muzeum niezwykłej piękności w Innsbrucku, właśnie ludowo tyrolskie. [...]

Innsbruck to niby nasz Nowy Targ i jako położenie, i jako funkcja (ale jako nic więcej). I znów zadumałem się smutno nad porównaniem góralszczyzny z Tyrolem. Naszej góralszczyzny. [...] O, muzeum owe w Innsbrucku! Ile tam świadectw wyobraźni, potrzeb, a przede wszystkim wszystko to jakby oparte na jakiejś solidnej podstawie materialnej, wystarczy porównać te ogromne, kamienno-drewniane jakby dwory, jakby farmy, piętrowe, zamki prawie wieśniacze tyrolskie $z$ naszymi ubożuchnymi dwoma izbami z sienią i dachem spadzistym, którego wynalazek jeszcze w szkole mi przedstawiano jako dowód błyskotliwej inteligencji tego plemienia, że to się niby nie zawali, jakby śnieg spadł. Gdybym był etnografem, to bym lansował teorię, że potrzeba, możność i umiejętność budowania i mieszkania $w$ piętrowych i skomplikowanie rozbudowanych pomieszczeniach kapitalnie na daną psychikę wpływa, względnie o niej świadczy ${ }^{21}$.

W całej relacji z podróży po Austrii natura jest prawie nieobecna. O pejzażach Mrożek pisze bardzo zdawkowo, napomyka o nich jedynie mimochodem i niemal natychmiast przechodzi do refleksji o charakterze kulturowym, gdyż - jak sam zauważa - widoki postrzegane przez szyby samochodu opisane dosłownie pozbawione byłyby jakiejkolwiek niezwykłości:

Przejazd przez Brenner miał coś z patosu, nie tyle ze względu na pejzaże, które dalekie od jakichkolwiek przepaści czy perci, choć piękne ogromne i rozłożyste, ile przez ścisłe kolumny samochodów zakosami idące i ginące w nieskończoność, a że jeszcze posuwały się krokiem piechura i ja wraz z nimi, co

20 Tamże.

21 Tamże, s. 453. 
dawało takie wrażenie, jak pochód ludu zakosami przez śniegi i aż w horyzont, ukazany przez Eisensteina w I części Iwana Groźnego. Tylko zresztą przy pomocy takich kulturalnych refleksji można jakąś niezwykłość z tego wydobyć, bo jeżeli ograniczysz się do dosłowności, to nie ma różnicy między przebywaniem Brenneru a dajmy na to posuwaniem się w zatorze przez Borek Fałęcki koło Kabla [...]. To niwelujące działanie samochodu już nieraz zaobserwowałem ${ }^{22}$.

Wydaje się jednak, że unikanie dosłownych opisów pejzaży nie jest jedynie efektem "niwelującego działania samochodu”, ale wynika z pewnych właściwości umysłu Mrożka, któremu obca była postawa „widzę i opisuję. W jednym $\mathrm{z}$ listów do Stanisława Lema tak oto wymiguje się od relacji z podróży do Jugosławii i Paryża:

Rzeczywiście, ani Jugosławii, ani ostatniego Paryża nie rozpracowałem tematycznie, ale są trudności, że tak powiem obiektywne, wiesz, że lubię pracować w sferze wniosków raczej niż opisu, które czasem krótkie i dosadne. Nie chciałbym razić Twoich uszu $[\ldots]^{23}$.

Fakt, że Mrożek wolał pracować „w sferze wniosków raczej niż opisu”, że musiał podróż „rozpracować tematycznie”, aby ją zrelacjonować, zapewne nie sprzyjał utrwalaniu konkretnych miejsc, w których pisarz mieszkał oraz tych, które odwiedzał, nie stanowi jednak wystarczającego wytłumaczenia tak znikomej ich obecności w jego listach i Dzienniku. Rozmawiając z Małgorzatą Niemczyńska już po opublikowaniu tego ostatniego, na jej uwagę, że w Dzienniku bardzo skupia się na sobie, niewiele zaś pisze o otoczeniu, odpowiedział:

Otoczenie było i jest cały czas, ale mnie to mniej interesowało. Szkoda na to czasu. Napiszę, kto gdzie był i kogo spotkałem, i co z tego? Pisałem o tym, co było ważne. Takie same byłyby te zapiski gdziekolwiek. Ja jestem dla mnie tak samo ważny jak otoczenie. Każdy człowiek tak ma ${ }^{24}$.

Brak potrzeby opisywania konkretnej przestrzeni geograficznej pozostaje, moim zdaniem, w ścisłym związku z silnie odczuwanym przez Mrożka problemem własnej tożsamości. Z prowadzonego w latach 1962-1989 Dziennika wyłania się obraz człowieka zmagającego się z obsesją nieistnienia, żyjącego w poczuciu tymczasowości i niedopasowania do aktualnej sytuacji, nomady bez żalu opuszczającego miejsca, które już go nie „karmiły”, lecz

\footnotetext{
22 Tamże, s. 456.

23 Tamże, s. 612.

24 M.I. Niemczyńska, Mrożek. Striptiz neurotyka, Warszawa 2013, s. 262-263.
} 
zaczynały „pożerać” 25 . Mrożek - jak sam stwierdził - żył przez cały czas w oczekiwaniu na zmianę, ,tak, jakby wszystko było [...] jedynie przygotowaniem do czegoś innego, po prostu stacją, ale nigdy celem podróży" ${ }^{26}$. Być może dlatego właśnie nie wspominał miejsc, z których uciekał, ani też nie odczuwał potrzeby opisywania tych, które były dlań tylko stacjami na drodze do nieokreślonego celu. Potrzeba taka pojawiła się dopiero wówczas, gdy pisarz był zmuszony opuścić Rancho La Epifania, które miało być miejsce jego „ostatecznego przeznaczenia", a stało się miejscem utraconym.

Każdy ma swoją the finest hour, [...] każdy ma w swoim życiu tę najpiękniejszą, najtrudniejszą, najwznioślejszą godzinę, która nie powtórzy się już nigdy.

Ci, którzy zaszli bardzo daleko i wrócili, nigdy nie umieli przystosować się w pełni do dawnego życia. Najprzeciętniejsi urzędnicy Imperium Brytyjskiego wysłani służbowo do Indii, gdy wracali do ojczyzny na emeryturę, nie wracali już tacy sami. Chcąc nie chcąc, byli już zarażeni przestrzenią i odmiennością.

Co tam urzędnicy, ci ostatecznie mieli w Indiach życie lepsze niż w domu. Ale opowiadał mi Niemiec, były jeniec niewoli rosyjskiej, jeden z nielicznych, którzy wrócili... Otóż on i paru jego kolegów, którym też udało się wrócić, już starsi i zamożni obywatele Republiki Federalnej Niemiec, zbierali się czasem w swoim gronie i popiwszy, tylko między sobą, śpiewali. Co śpiewali? Rosyjskie tęskne pieśni, które słyszeli wieczorami, przed laty, spoza drutów. Śpiewali i wspominali rosyjski księżyc. A przecież wiadomo, jakie mieli życie w rosyjskim obozie.

Jestem pewien, że nieraz będę śpiewał meksykańskie pieśni na tle hejnału mariackiego. Tym bardziej, że - w odróżnieniu od Niemca w niewoli rosyjskiej - oprócz chwil, godzin i lat trudnych i strasznych miałem tu chwile, godziny i lata wspaniałe. Miexico, my finest hor [Dp, s. 36].

Z kolei miejsca z przeszłości odżyły we wspomnieniach Mrożka, kiedy po przebytym w maju 2002 roku udarze mózgu, musiał ponownie określić siebie i odzyskać orientację w świecie utraconą w wyniku choroby. Wróciwszy ze szpitala do domu, pisarz zdał sobie sprawę z faktu, iż nie jest w stanie wykonać najprostszych czynności:

Usiadłem na krześle i posiedziałem przez chwilę. Ale gdy wstałem, wszystko zawirowało. Nie wiedziałem jeszcze, że moja zdolność do percepcji otaczającego mnie świata, znajomość pojęć przeciwstawnych, takich jak na przykład góra i dół, prawo i lewo, oraz zdolność do określenia odległości czy czasu, uległy

2517 lipca 1986 roku Mrożek zanotował w Dzienniku: „Kiedyś nie wiedziałem, że jestem nomadą. Wydawało mi się, że jestem pielgrzymem. Zasadnicza to różnica", S. Mrożek, Dziennik, t. 3, s. 635 .

26 Tamże, s. 752. 
znacznemu ograniczeniu. Zrozumiałem, że od tej pory będę musiał mozolnie pracować, aby odzyskać to, co utraciłem. A oto bilans mojej klęski.

Znałem kilka języków obcych. Po powrocie ze szpitala okazało się, że nie potrafię rozmawiać $\mathrm{w}$ żadnym $\mathrm{z}$ nich.

Język polski, będący moim ojczystym językiem, stał się nagle niezrozumiały. Nie potrafiłem ułożyć żadnego sensownego zdania.

Potrafiłem czytać, jednak nie rozumiałem tego, co przeczytałem.

Utraciłem umiejętność posługiwania się maszyną do pisania, komputerem, faksem i telefonem. Nie wiedziałem też, jak posługiwać się kartą kredytową.

Nie umiałem liczyć i nie mogłem odnaleźć się w kalendarzu.

Konieczność wyjścia na ulicę budziła we mnie zdecydowany sprzeciw. Panicznie bałem się spotkania $\mathrm{z}$ obcymi.

Jedyne, co mi pozostało, to umiejętność słuchania muzyki. Poczułem, że teraz rozumiem ją znacznie lepiej, zwłaszcza kiedy zamykam oczy ${ }^{27}$.

Za namową lekarza Mrożek poddał się terapii logopedycznej, w efekcie której zaczął powoli odzyskiwać orientację w czasie i przestrzeni oraz zdolność komentowania tego, co się wokół niego działo. Odzyskawszy mowę, postanowił z kolei podjąć próbę powrotu do zawodu i zachęcony przez swoją terapeutkę przystąpił do pisania książki, zatytułowanej roboczo Dziennik powrotu - ciag dalszy, która ostatecznie ukazała się w roku 2006 jako Baltazar. Autobiografia. Pisanie autobiografii, w trakcie którego pisarzowi stopniowo powracała pamięć, było więc terapią $\mathrm{w}$ dosłownym tego słowa znaczeniu. W jej wyniku we wrześniu 2005 roku, w momencie kończenia książki, Mrożek był „W stanie przypomnieć sobie znacznie więcej wydarzeń" [B, s. 9] i potrafił je zapisać, co pozwoliło mu uwierzyć, że z czasem będzie coraz sprawniej posługiwał się językiem i odzyska „zdolność pisania na tyle, na ile jest to możliwe po afazji" [B, s. 10].

Nadając swojej autobiografii tytuł Baltazar, Mrożek podkreślił fakt, że po przebytej chorobie nie był już tym samym człowiekiem, co wcześniej. Nowe nazwisko wyśnił sobie podczas pobytu w Paryżu w grudniu 2003 roku, a więc już po udarze. Zobaczył je wypisane na urzędowym druku w języku polskim. $Z$ dokumentem tym miał się udać za granicę i przedstawić go tamtejszym władzom, które miały spełnić jego żądania pod warunkiem, że nigdy nie użyje już swojego prawdziwego imienia i nazwiska. Opisując ów sen w autobiografii, Mrożek skomentował go następująco:

Obudziłem się pod wrażeniem tego snu. Baltazar... Nigdy przedtem nie byłem entuzjastą mojego nazwiska. Towarzyszyło mi zawsze jako nudna koniecz-

\footnotetext{
27 S. Mrożek, Baltazar. Autobiografia, s. 244-245. Kolejne cytaty z Baltazara lokalizuję w tekście głównym, oznaczając je skrótem B.
} 
ność. Później, kiedy zacząłem już pisać, było przy mnie przez wzgląd na mojego ojca. Aż do momentu, w którym zostałem dotknięty afazją [B, s. 241].

Afazja były dla Mrożka - jak to sam określił - katastrofą, ale paradoksalnie uwolniła go od frustracji związanej z uświadomieniem sobie faktu, że się starzeje i nie nadąża za otaczającym go światem:

Niespodziewanie „na pomoc” przyszła mi afazja. Podziałała na mnie jak samobójstwo, które się nie udało, ale pozostawiło nieznaczne ślady i nie można już ich usunąć. Ale ja, zmieniając nazwisko i podpisując się „Baltazar”, przyznaję się otwarcie do niedoskonałości. Odtąd nie można mnie chwalić ani ganić za nic, co napisałem przed afazją, ponieważ tamten człowiek nie istnieje [B, s. 248].

Utrata zdolności posługiwania się innym językiem niż polski zmieniła także stosunek pisarza do kraju ojczystego:

Druga sprawa to moja przynależność do Polski. Cokolwiek jeszcze napiszę, nie będzie wątpliwości, że przynależę do Polski. A jeszcze niedawno bywało różnie. Przyzwyczajony do swobody i będąc w pełni sił, nie mogłem się oswoić z myślą, że Polska jest moim przeznaczeniem. Ale teraz mogę mówić i pisać tylko po polsku i odczuwam ulgę jak ktoś, kto po długiej wędrówce zawitał do rodzinnego domu [B, s. 249].

Wprawdzie w 2008 roku Mrożek ponownie wyemigrował z Polski i osiedlił się w Nicei, jednak tym razem o wyjeździe zadecydowały, jak pisze Małgorzata Niemczyńska, względy zdrowotne - lekarz doradził mu zmianę klimatu. W rozmowie z Niemczyńską na pytanie o to, czy mógłby mieszać gdziekolwiek, odpowiedział: „Teraz już nie. Teraz mieszkam w Nicei, przypuszczam, że tak pozostanie. Odpowiada mi tam klimat. Jest słonecznie i ciepło. Chodzę na spacery" ${ }^{28}$. W związku z powyższym można by się oczywiście zastanawiać, czy zadeklarowane przez Mrożka pogodzenie się z przynależnością do Polski nie było chwilowe, wydaje się jednak, że fakt przeprowadzki do Nicei nie podważa autentyczności owej deklaracji. Pisana $\mathrm{w}$ ramach terapii autobiografia dokumentuje nie tylko proces wychodzenia $\mathrm{z}$ afazji, ale też rekonstruowania tożsamości poprzez usytuowanie siebie w czasie i przestrzeni, przy czym zasadniczą część Baltazara poświęcił Mrożek czasom dzieciństwa i młodości, a więc temu okresowi życia, który spędził w Polsce. Odtwarzając swoją przeszłość, pisarz wspomina nie tylko ludzi i zdarzenia, ale też powraca pamięcią do miejsc, które odcisnęły swoje piętno na jego biografii: Borzęcina, Porąbki Uszewskiej, Kamienia w województwie rzeszowskimi i oczywiście Krakowa.

28 M.I. Niemczyńska, Mrożek. Striptiz neurotyka, s. 263. 
Kraków, w którym Mrożek mieszkał od 3 do 29 roku życia i do którego powrócił po 33 latach emigracji, uobecnia się na kartach Baltazara najczęściej. Wyjaśniwszy na początku pokrótce okoliczności, w jakich zapadła decyzja o przeprowadzce z Meksyku do Europy i zamieszkaniu w Krakowie, w następujących po sobie rozdziałach pisarz ukazuje to miasto $z$ dwóch odległych perspektyw czasowych. Jako pierwsze pojawia się wspomnienie przyjazdu do Krakowa we wrześniu 1996 roku:

Z mnogości wrażeń zostały mi w pamięci tylko topole. Ile razy przypominam sobie ten moment, pojawiają się ich sylwetki - wysmukłe i drżące, choćby przy najmniejszym wietrze. A Kraków dopiero w nieokreślonym tle.

Drogę do miasta odbyliśmy w deszczu. Jaki ten Kraków mały! Nigdy wcześniej mi się taki nie wydawał, a przecież byliśmy tu już wiele razy. Już Wola Justowska, hotel Cracovia i zaraz potem stanęliśmy przy Starym Teatrze [B, s. 16].

Aklimatyzacja w mieście, w którym pisarz dorastał, nie przebiegała łatwo. Od momentu wylądowania dręczyła Mrożka powracająca myśl: „Co ja właściwie tutaj robię?" [B, s. 16], a dodatkowo pobyt w Krakowie utrudniały $\mathrm{mu}$ „powracające widma”. Wspomnienia z przeszłości sprawiały, że spacerując ulicami miasta, doświadczał swoistego podwojenia czasu. W zbliżającym się z naprzeciwka młodym człowieku rozpoznawał nagle siebie sprzed pięćdziesięciu lat. Wprawdzie na pierwszy rzut oka Kraków zmienił się dość znacznie, $w$ istocie jednak pozostał tym samym miastem, jakim był wcześniej. Zachował swój specyficzny, irytujący z perspektywy kogoś, kto objechał kawał świata, charakter:

Zmiany, jakie zastałem, dotyczyły głównie sposobu, w jaki toczyło się codzienne życie krakowian. Zmienił się ubiór, pożywienie, a nawet ich mieszkania w nowych dzielnicach Krakowa. I, co najważniejsze, nie była to już „Polska Rzeczpospolita Ludowa", tylko po prostu Polska. Nie ulega wątpliwości, że były to zmiany na lepsze. Ale pozostały inne przyzwyczajenia, jak choćby akcent krakowski, który poznałem, gdy tylko nauczyłem się mówić. Albo ta sama wyniosłość w traktowaniu przybyszów pochodzących z innych części Polski, czyli skłonność do uważania się za kogoś lepszego. Ten sam partykularyzm, te same "wianki” w lecie i te same bale w zimie. Kiedyś, kiedy byłem jeszcze cząstką Krakowa, przystawałem na to $z$ ochotą. Teraz, po objechaniu sporej części świata, wydawało mi się śmieszne [B, s. 23].

Na zasadzie kontrastu do obrazu Krakowa widzianego oczami przybysza z wielkiego świata ukazuje Mrożek w kolejnym rozdziale Baltazara swój „wczesny Kraków”:

Na początku Kraków nie był mały. [...] Do Krakowa zawitaliśmy, gdy miałem trzy lata. Zamieszkaliśmy w Prokocimiu. [...] Jakże niewielką liczbę mieszkańców miał wtedy Kraków. W porównaniu z dniem dzisiejszym - było pusto. 
Stąd miało się wrażenie wszechobecnej prowincji, choć prowincji było akurat tyle samo, ile i dzisiaj.

Kraków to było pierwsze miasto w moim życiu. Różnica między miastem a wsią była w tych czasach znacznie większa niż obecnie. Sam fakt stąpania po bruku czy po asfalcie, a nie po wiejskiej drodze, pozostał dla mnie odkryciem na zawsze zapamiętanym. Dodam także, że w czasach mojego dzieciństwa na wsi nie było światła elektrycznego.

W Prokocimiu domki rozsiane były rzadko i prawie wszystkie były parterowe. Droga była ziemna, jesienią i na wiosnę błotnista. Ale już o piętnaście minut drogi koleją był Kraków, a w nim pełnia życia, ruchu i ekscytujących przygód. Byłem mały i nie było potrzeby, abym jeździł do Krakowa. Ale obecność była wyczuwalna, nawet na przedmieściach [B, s. 29-30].

W samym Krakowie pisarz zamieszkał w roku 1935, kiedy to jego rodzina przeniosła się najpierw do mieszkania przy ul. Bandurskiego, a następnie przy ul. Kieleckiej. Wspomnienia z tego okresu ze zrozumiałych względów nie zawierają zbyt wielu detali topograficznych. W pamięci Mrożka zapisały się przede wszystkim emocje związane z przeprowadzką do prawdziwego miasta oraz pewne wrażenia, takie jak na przykład „odkrycie nieba”, spowodowane najprawdopodobniej - jak sam zauważa - tym, że po raz pierwszy zamieszkał na „niebotycznej wysokości”, bo aż na czwartym piętrze. Szczegółowe opisy topograficzne pojawiają się dopiero we wspomnieniach dotyczących czasów późniejszych. Bardzo dokładnie odtwarza Mrożek drogę z ul. Kieleckiej do Podgórza, do którego jego rodzina musiała się przeprowadzić w listopadzie 1943 roku, a następnie z niezwykłą precyzją opisuje usytuowanie nowego mieszkania:

Wzdłuż Wisły, od Trzeciego Mostu do Rynku Podgórskiego, rozciągały się drobne fabryczki i warsztaty. Tam znajdowało się nasze mieszkanie. Wchodziło się do domu przez sień i na lewo, po spiralnych schodkach, na płaski dach garażu. Po przejściu kilkunastu metrów szło się znowu po schodkach w górę, na prawo. Tu nagle kończyła się ściana zabezpieczona wąską poręczą. Przechylając się nad poręczą, w dole, przed garażem, można było zobaczyć bruk. Teraz należało wykonać półobrót w lewo i już staliśmy przed wąskimi drzwiami. Po otwarciu tych drzwi wchodziło się do bardzo małego pokoju z oknem. Idąc na wprost przez kolejne drzwi, można było przejść do równie małej kuchni. Przez okno było widać jednolity szary mur, oddalony o jakieś dwa metry od okna. W kuchni, przy dziennym świetle, było prawie ciemno. Kiedy chcieliśmy z niej skorzystać musieliśmy używać światła elektrycznego. Gdy wyglądałem przez okno kuchenne, mogłem zobaczyć dwupiętrową studnię zasłaną odpadkami niewiadomego pochodzenia [B, s. 85].

Przeprowadzka do Podgórza była dla Mrożka wielkim przeżyciem i dlatego przebyta wówczas droga oraz sam moment wejścia do domu głęboko 
zapadły mu w pamięć, na co zresztą sam zwraca uwagę, tłumacząc się ze szczegółowości opisu. Niewątpliwie jednak drobiazgowe odtworzenie lokalizacji nowego mieszkania nie byłoby możliwe, gdyby pierwsze wrażenie nie zostało dodatkowo wzmocnione. W Podgórzu Mrożek mieszkał wraz z rodzicami od listopada 1943 roku do końca czerwca 1944 i drogę do domu pokonywał codzienne, idąc do szkoły i z powrotem. Fakt ten przypuszczalnie $\mathrm{w}$ większym stopniu niż emocje towarzyszące przeprowadzce przyczynił się do tego, że zapamiętał to miejsce tak dokładnie.

Opisywany w Baltazarze Kraków to przede wszystkim domy, w których Mrożek mieszkał i ich najbliższe okolice. Obok już wymienionych pisarz wspomina również swoje lokum na strychu w domu Leszka Herdegena przy ul. Świerczewskiego i niewielki pokoik w Domu Literatów przy ul. Krupniczej 22. Z oczywistych względów przestrzenie, by tak rzec, na co dzień praktykowane najtrwalej zapisały się $\mathrm{w}$ pamięci pisarza i mogły zostać $\mathrm{z}$ niezwykłą precyzją odtworzone. Niewątpliwie jednak również emocje miały istotny wpływ na trwałość i charakter niektórych wspomnień o miejscach, w których Mrożek przebywał w dzieciństwie i młodości. Widać to wyraźnie $\mathrm{w}$ opisach Borzęcina, $\mathrm{z}$ którego pochodziła matka pisarza i w którym przyszedł na świat, Porąbki Uszewskiej - rodzinnej wsi ojca oraz Kamienia, w którym mieszkał stryj Ludwik Kędzior.

We wspomnieniach Mrożka utrwalił się Borzęcin z okresu drugiej wojny światowej, na początku której cała rodzina ze strony matki zjechała do domu dziadka Jana Kędziora. Otoczony sporym ogrodem dom „był dziwnie mały" [B, s. 48]. Składał tylko z dwóch izb, a pod tym samym dachem znajdowała się również mleczarnia. Na niewielkiej przestrzeni musiało się pomieścić czternaście osób, z tym że dwanaście spośród nich miało do dyspozycji

jeden dwuokienny pokój, dwa łóżka i maleńką kuchnię. W kuchni rozkładano na noc posłanie, ale ciasnota była wielka. Dziadek i jego żona mieszkali osobno, w pokoju oddzielonym od naszej części werandą i drugimi drzwiami. Stosunki między nami były chłodne. Co chwila drzwi od "tamtego" pokoju otwierały się i ukazywała się w nich „żona ojca”, a mojego dziadka. Przechodziła przez nasz pokój, wchodziła po trzech stopniach do kuchni, stawała przy piecu coś gotując, a następnie wychodziła z powrotem i znikała za drzwiami. Gotowanie przy piecu było wspólne, choć niejednakowe dla nich i dla nas. Jadali w osobnym pokoju, do którego nikt z nas nie miał wstępu [B, s. 62].

Właściwie na tym opisie domu wyczerpują się „przestrzenne” wspomnienia Mrożka z Borzęcina, tak jakby doświadczenie ogromnej ciasnoty przesłoniło wszystko inne. Najbliższe otoczenie domu dziadka Kędziora wy- 
łania się jedynie $\mathrm{z}$ rozproszonych uwag, z których wynika, że w jego sąsiedztwie znajdował się dom wdowy po kierowniku szkoły, pani Rogożowej, gdzie było mnóstwo książek. Tuż obok wznosił się również piętrowy budynek z salą teatralną zwany Domem Katolickim, gdzie ulokowała się żandarmeria niemiecka. Obraz ten dopełnia wzmianka o oddalonym o dwa kroki od domu dziadka cmentarzu, na którym pochowana została matka pisarza.

Bogatsze w szczegóły topograficzne są wspomnienia Mrożka z Porąbki Uszewskiej, rodzinnej wsi ojca, o czym zapewne w znacznej mierze zadecydowało usytuowanie zagrody dziadka Ignacego Mrożka sprzyjające ich zapamiętaniu. Opis Porąbki rozpoczyna pisarz w sposób typowy dla przewodników turystycznych od szerokiej panoramy okolicy, w jakiej się znajdował się dom dziadków:

Porąbka Uszewska leży na południe od linii kolejowej Kraków-Tarnów. Po przekroczeniu tej linii teren podnosi się i Porąbka leży już na pogórzu, w kierunku na Gorce. Wieś ułożona jest wzdłuż rzeki, pomiędzy dwoma sporymi i stromymi górami, zwanymi Bocheniec i Głodów. Zagroda dziadka znajdowała się na południe od Głodowa i patrząc z góry na kościół oraz na plebanię koło rzeki, po jej drugiej stronie widziało się każdy szczegół i figurki ludzi.

Zagroda nie była duża. Pod jednym dachem, krytym słomą, mieściła „komorę", oborę dla obu krów, kuchnię, izbę - a po przejściu przez sień - izbę reprezentacyjną, tę $\mathrm{z}$ widokiem na kościół $\mathrm{w}$ dole. Tylko izba i izba odświętna miały podłogę. $\mathrm{W}$ innych pomieszczeniach było klepisko. $\mathrm{Z}$ zewnątrz zagroda była malowana na bladoniebieski kolor, przecinała ją polna droga, a w ogródku rosły kwiaty [B, s. 53].

Znaczący wpływ na utrwalenie się w pamięci Mrożka tego obrazu miał również jego emocjonalny stosunek do dziadków. W najwcześniejsze wspomnieniach z Porąbki nieodłącznie towarzyszy mu "mała, drobna, wiecznie zatroskana" [B, s. 53] babka, którą lubił i darzył zaufaniem, oraz cechujący się łagodnym usposobieniem dziadek, który jako kościelny musiał pracować podwójnie: „najpierw troszczył się o święte sprawy, a dopiero potem spełniał obowiązki cywilne" [B, s. 54], nigdy jednak nie uskarżał się na swój los i był zawsze pogodny.

O tym, że to właśnie ludzie i związana z nimi aura miejsca decydują o trwałości wspomnień dowodnie świadczy bardzo obszerny i drobiazgowy opis znajdującej się w Kamieniu koło Rzeszowa posiadłości stryja Ludwika, bratanka dziadka Jana Kędziora. W przeciwieństwie do starego Kędziora, który "był skąpcem, młody miał szeroki gest” [B, s. 66], prowadził bujne życie towarzyskie i otaczał się "haremem” ładnych służących. „Nie truł, i nie moralizował, swoje sprawy zachowywał dla siebie, a jednocześnie dawał 
wszystkim szansę" [B, s. 35-36]. Niewątpliwie odmienność stryja Ludwika od innych wujków, sprawiała, że trzy pobyty w Kamieniu (latem 1939 roku, od jesieni 1940 do jesieni 1941 i podczas wakacji w roku 1949) oraz lokalizacja domostwa głęboko zapadły Mrożkowi w pamięć, choć nie bez znaczenia było również to, że jesienią 1940 roku Mrożkowie przybyli do Kamienia z Borzęcina, z którego wyjechali z powodu uciążliwej ciasnoty. Na tym tle posiadłość stryja Ludwika przedstawiała się szczególnie okazale:

Stryj Ludwik miał [...] trzy domy, a właściwie to dwa i pół. Pierwszy dom od ulicy, opatrzony masywna bramą, pochodził z dziewiętnastego wieku. Pokryty był strzechą, siwym wapnem i miał niewielkie okiennice. Ale w środku był wygodny. Wielka, bez porównania większa niż w Borzęcinie i dobrze wyposażona kuchnia była ośrodkiem, w którym koncentrowało się życie domu. Tutaj przychodzili wszyscy, którzy mieli cokolwiek do załatwienia, i wielu z nich zasiadało do stołu, ponieważ stryj był smakoszem i lubił towarzystwo.

Dom był podzielony sienią. Kuchnia mieściła się z prawej strony, a z lewej - trzy pokoiki. Po drugiej stronie obejścia stał obszerny piętrowy tak zwany spichlerz, w którym przechowywano wszystko, tylko nie zboże. Szyny kolejki wąskotorowej zaczynały się tuż przy spichlerzu i biegły przez cały teren aż do stawów. Kolejka była potrzebna do transportu desek z tartaku i w ogóle do wszystkiego, czego nie opłacało się nosić, na przykład do przewożenia worków z mąką albo ziarnem.

Po drodze mijało się parterowy budynek przeznaczony na zapasowe części do motocykli. Dalej stał młyn. Był to budynek piętrowy, sczerniały, z oknami zabezpieczonymi siatką. Obok rozciągał się obszerny majdan dla wozów i koni. Do młyna - tak że jego bok był częścią ściany - przylegał apartament stryja Ludwika.

Obchodząc dookoła, można było zajrzeć po drodze do potężnej maszyny parowej. Było to serce młyna i tartaku. W piecu paliło się trocinami, których zwały piętrzyły się $\mathrm{w}$ bezpiecznej odległości. W tartaku przerabiano pnie drzew na deski za pomocą piekielnej maszyny. Panował potworny hałas, przez który żaden głos się by się nie przebił, toteż po wyjściu można było odetchnąć z ulgą.

Na granicy posiadłości znajdował się staw, a na półwyspie jeszcze jeden dom. Nieraz starałem się wejść do domu przez werandę, ale drzwi były zamknięte na klucz. Gdy zbliżyło się twarz do okna, można było dostrzec łóżko i strome schody wiodące na piętro [B, s. 68].

W owym tajemniczym domku nad stawem zamieszał Mrożek podczas wakacji w 1949 roku. Tym razem pobyt w Kamieniu był wytchnieniem od nieznośnej sytuacji w rodzinnym domu w Krakowie, w którym życie uprzykrzały mu częste awantury między ojcem i siostrą. Niekontrolowany przez nikogo mógł zwiedzać okolice i cieszyć się niczym nieograniczoną swobodą:

Wieczorami po kolacji, która odbywała się w kuchni starego domu, żegnałem stryja Ludwika i szedłem rzekomo spać. Zresztą i tak nikt tego nie sprawdzał. 
Gdy zbliżałem się do domku nad stawem, zamiast skręcić w lewo, szedłem w prawo i przeskakiwałem przez parkan. Po drugiej stronie nie było nikogo, puste pole, a potem zaczynał się las. Zapalały się gwiazdy na czystym niebie. Różne szelesty rozlegały się wokół. Zaczynałem biec lekko i bez wysiłku. Tak biegają dziewiętnastoletni i zdaje im się, że mogą tak biec bez końca. Czysta radość dodaje im skrzydeł, stopy nie dotykają ziemi, a serce pracuje $\mathrm{w}$ doskonałym rytmie. Kiedy dobiegałem do lasu, wschodził właśnie księżyc. Wtedy las się przemieniał i stawał się zaczarowany. Ja też się przemieniałem i stawałem się jednością z księżycem, lasem, nocą. Tak przynajmniej wydaje mi się dzisiaj, kiedy takie przygody są już dawno utracone [B, s. 125-126].

Z jednej strony szczególna aura miejsca, z drugiej okoliczności, w jakich Mrożek przebywał w posiadłości stryja Ludwika, sprawiły, że to właśnie Kamień, a nie Borzęcin czy Porąbka Uszewska, w których spędził więcej czasu, został przez niego tak dokładnie zapamiętany. Być może zadecydował o tym również fakt, że doświadczył tu swoistej przestrzenności, która zawsze kojarzyła mu się z wolnością.

Zawarte w Baltazarze opisy miejsc nie mają szczególnych walorów literackich, przypominają raczej szkolne ćwiczenia, bo właśnie jako ćwiczenia służące odzyskaniu zdolności pisania powstawały. Przywołane zostały tu tak obszernie ze względu na ich wartość dokumentacyjną. Zaskakująca dokładność tych opisów potwierdza wyrażony przeze mnie wcześniej pogląd, że Mrożek był pisarzem o rozwiniętej wyobraźni topograficznej, wrażliwym na otaczającą go przestrzeń i doświadczającym jej somatycznie. Nie przejawiał wprawdzie skłonności do utrwalania konkretnych miejsc, ale nie był też na nie obojętny. Po przebytej chorobie niektóre z nich stały się ważnymi punktami orientacyjnymi w czasie i przestrzeni umożliwiającymi pisarzowi zrekonstruowanie własnej tożsamości. Pamięć o miejscach, które go kształtowały, okazała się dla „urodzonego wędrowca” ocalająca.

\section{"Jestem urodzonym wędrowcem". On Autobiographical Places of Sławomir Mrożek}

\section{Summary}

The subject of reflections in this article is the phenomenon of topographic imagination of Sławomir Mrożek. Tracking traces of autobiographical places in the writer's works, the author attempts to explain the reasons for his little interest in the geographic concrete as a literary material as well as to answer the question what functions these places fulfill in Dziennik powrotu [A Journal of Return] and Baltazar. Autobiografia [Balthasar. Autobiography]. In her opinion, both the scarce presence of autobiographic 
places in the earlier works of Mrożek, as well as their appearance in the works referred to, remains in connection with the problem of the identity of the writer, who throughout most of his life struggled with the sense of non-existence, and after the stroke he had to redefine himself and his place in the world.

Keywords: geographical space, autobiographical places, topographic imagination, Sławomir Mrożek 